\title{
Xenodiagnosis of Leishmania donovani in BALB/C mice using Phlebotomus orientalis: a new laboratory model
}

\author{
Jovana Sadlova ${ }^{1 *}$, Veronika Seblova ${ }^{1}$, Jan Votypka', Alon Warburg ${ }^{2}$ and Petr Volf ${ }^{1}$
}

\begin{abstract}
Background: In areas endemic for visceral leishmaniasis $(\mathrm{VL})$, the majority of infected hosts remain asymptomatic but potentially infectious to biting sand flies. Their infectiousness for sand fly vectors is crucial for the transmission of the disease and can be quantified only by xenodiagnosis. However, in the case of human hosts, xenodiagnosis can be problematic for ethical and logistic reasons. The BALB/C mouse model described in this paper was designed to enable xenodiagnostic studies on VL hosts circumventing the need for human volunteers, it permits xenodiagnosis using the same individual host repeatedly, over several months.

Methods: BALB/c mice were intradermally inoculated in the ear pinnae with Leishmania donovani, primarily metacyclic stages isolated from the thoracic midguts of experimentally-infected Phlebotomus orientalis females. Naïve sand flies were allowed to feed on anaesthetized mice in 1-3-weeks- interval, firstly on the site of inoculation of $L$. donovani (weeks 2-8 post infection, p.i.), later on the whole body of mice (weeks $9-15$ p.i.). Infections of sand flies were evaluated microscopically or by PCR analysis.

Results: Although infected mice did not show any signs of disease, $19 \%(N=876)$ of the $P$. orientalis females that fed at the site of inoculation, became infected. The majority of L. donovani-positive females (76\%) had heavy infections with their stomodeal valves colonized by attached parasites. Inoculated mouse ears remained infective for sand flies until week 15 p.i. Females feeding on other parts of the body remained negative with exception of two groups feeding on contralateral ears by week 12 p.i. On week 15, however, these two mice returned negative at xenodiagnosis of the contralateral ears. In sacrificed mice, the highest parasite numbers were found in inoculated ears and their draining lymph nodes. Infections were detected also in the spleen, liver, blood and rarely in the contralateral ear.
\end{abstract}

Conclusions: The study showed that BALB/c mice harbored parasites in sufficient numbers to promote heavy infections in P. orientalis and thus comprised a suitable laboratory model for xenodiagnoses of L. donovani. Parasites persisted in the inoculation site and were found transmissible for months to sand flies biting on the same site.

Keywords: Xenodiagnosis, Visceral leishmaniasis, Phlebotomine sand flies, Asymptomatic reservoir hosts, Vector-borne diseases, Leishmania donovani

\footnotetext{
* Correspondence: sadlovaj@natur.cuni.cz

${ }^{1}$ Department of Parasitology, Faculty of Science, Charles University in Prague,

Prague 2 Vinicna 7, 128 44, Czech Republic

Full list of author information is available at the end of the article
} 


\section{Background}

Visceral leishmaniasis (VL), also known as kala-azar, is caused by Leishmania parasites belonging to the $L$. donovani complex (Kinetoplastida: Trypanosomatidae) and transmitted by phlebotomine sand flies (Diptera: Psychodidae). The disease is prevalent among mainly poor rural and suburban populations in Asia, Africa and Latin America. An estimated 390,000 VL cases occur annually, over $90 \%$ of which are concentrated in the Indian sub-continent, East Africa and Brazil [1]. Epidemiology of two causative agents of the disease, $L$. donovani and $L$. infantum, significantly differs; while $L$. infantum circulates as zoonosis with dogs serving as the main reservoir hosts, closely related $L$. donovani is mostly assumed to be anthroponotic $[1,2]$.

VL caused by $L$. donovani is a serious systemic disease but most humans infected with $L$. donovani remain asymptomatic - i.e. positive by serology, polymerase chain reaction (PCR) and/or Leishmanin Skin Test (LST), but free of disease. The ratio of asymptomatic to patent infections ranges from 1:2.4 to 5.6:1 in East Africa and from 4:1 to 9:1 in the Indian subcontinent (reviewed by [3]) Importantly, asymptomatic individuals with amastigotes in their blood or skin are potentially infectious to biting sand flies and may serve as "cryptic" reservoir hosts.

A crucial factor in the spread of vector-borne diseases is the propensity of infected hosts to serve as parasite reservoirs for the vectors. Moreover, for the implementation of effective control of VL it is essential to estimate to what extent asymptomatic hosts are responsible for infecting the vector sand flies. Mathematical modeling based on data from the Indian subcontinent indicated that transmission of $L$. donovani is predominantly driven by asymptomatic persons, whose incidence is much higher than symptomatic VL cases [4]. A cohort study conducted in north Ethiopia calculated that only about $3.2 \%$ of the asymptomatic human carriers of $L$. donovani (k-DNA qPCR positive) had sufficiently high parasitaemias (>1000 parasites per $\mathrm{ml}$ of blood) to infect sand flies efficiently. These asymptomatic carriers with high parasitaemias were mathematically estimated to be responsible for about $65 \%$ of the infected sand flies [5]. It should be noted that in highly susceptible vectors like $P$. orientalis, as few as one or two parasites per bloodmeal were demonstrated to establish infection in $50 \%$ of sand fly females [6].

The optimal method for testing the infectiousness of hosts to biting vectors is by xenodiagnosis. Such studies have been performed predominantly with $L$. infantum. Many studies on dogs described the correlation between clinical symptoms and infectiousness to biting sand flies. Meta-analysis of these studies showed that asymptomatic dogs infect similar proportions of biting sand flies as do symptomatic ones [7]. In humans, two xenodiagnostic studies have been performed. The study on human volunteers showed that Brazilian VL cases were infectious to feeding sand fly females while volunteers who were asymptomatic, were not [8]. However, in this study, asymptomatic infections were identified using LST that detects only late-stage cell-mediated immunity [9]. Hence, these LST positive volunteers may have already harbored low parasitaemias or could have even been parasite-free. The second study by Molina et al. [10] found both asymptomatic and symptomatic patients infective for Phlebotomus perniciosus sand flies.

Several studies on cutaneous leishmaniasis (CL) have established that sand fly bites result in infections characterized by typical immune reactions and distinct pathologies from infections delivered by injection [11-13]. Clearly transmission of the parasite is the crucial stage for infecting the hosts; however, the transmission dynamics of the disease are affected much more significantly by the infectiousness of the hosts for naïve sand flies. While an individual host can only be infected once, it may infect a large number of sand flies for prolonged periods. Hence the infectiousness of the host is the crucial driver of transmission in vector-borne diseases [5].

Leishmania donovani s. str. is assumed to circulate anthroponotically among humans; a role for animal reservoir hosts has been suggested but not conclusively proven. Performing xenodiagnostic studies with human volunteers is highly problematic for ethical and logistical reasons. Therefore, we established a BALB/c mouse model for xenodiagnosis of VL circumventing the need for human volunteers. Using the mouse model we were able to (i) perform xenodiagnosis with the same host repeatedly during several months and (ii) expose the whole body of the host to biting sand flies. This facilitated the collection of data about temporal and spatial patterns of infectiousness of mice without external signs of disease for sand flies. Such data may promote improved understanding of the transmission dynamics and epidemiology of VL.

This is the first paper to characterize the infectiousness profile for biting sand flies of hosts without external signs of disease infected with $L$. donovani. BALB/c mice were intradermally inoculated with $L$. donovani and exposed to biting $P$. orientalis, the vector of $\mathrm{VL}$ in north Ethiopia and Sudan [14]. Like asymptomatic human cases, experimentally infected mice harbored $L$. donovani parasites for many weeks without showing any apparent symptoms. We studied the time course of the infectiousness of mice for sand flies and compared the relative proportions of sand flies infected by feeding on different parts of the body. 


\section{Methods}

\section{Sand flies and parasites}

Phlebotomus orientalis colony was maintained under standard conditions $\left(26^{\circ} \mathrm{C}\right.$ on $50 \%$ sucrose and $14 \mathrm{~h}$ light/10 h dark photoperiod) as described previously [15]. Leishmania donovani (MHOM/ET/2010/GR374) was cultured in M199 medium (Sigma) containing 10\% heat-inactivated fetal calf serum (Gibson) supplemented as described by Sadlova et al. [16]. Cultivations of parasites from mouse spleens were done on blood agar slopes overlaid with the same medium.

\section{Infections of BALB/c mice with sand fly-derived Leishmania}

$P$. orientalis females were infected with $L$. donovani by feeding through chick-skin membranes on heparinized rabbit blood containing $10^{6}$ promastigotes $/ \mathrm{ml}$. Engorged females were maintained at $26^{\circ} \mathrm{C}$ on $50 \%$ sucrose and dissected on day 10 or 12 post bloodmeal (PBM); their midguts were checked microscopically for the presence of promastigotes and thoracic midguts (the site of accumulation of metacyclic forms) with good density of parasites, were pooled in sterile saline. Pools of freshly dissected 70 thoracic midguts were homogenized in $35 \mu$ l saline. Immediately, BALB/c mice anaesthetized with ketamin/xylazin (150 $\mathrm{mg}$ and $15 \mathrm{mg} / \mathrm{kg}$, respectively) were injected with $5 \mu \mathrm{l}$ of the parasite suspension intradermally into the inner sides of ear pinnae using syringe. Exact numbers of all parasites stages were calculated using a Burker apparatus and the proportions of metacyclic forms was identified on Giemsa stained smears based on morphological criteria described previously [17]. In two repeats of the experiment, L. donovani numbers in the inoculums were $1.4 \times 10^{5}$ and $9.3 \times 10^{4}$ per mouse, metacyclics comprised $65 \%$ and $73 \%$ of all forms, i.e., $9.1 \times 10^{4}$ and $6.8 \times 10^{4}$ per mouse. Mice were checked weekly for external signs of the disease till week 8 or 15 post infection (p.i.) when they were sacrificed.

\section{Xenodiagnosis I}

The first series of xenodiagnosis experiments was performed between weeks 2 and 8 p.i. Five to seven-day-old $P$. orientalis females were allowed to feed on the inoculated ear (the site of inoculation of $L$. donovani) of anaesthetized mice in two-weeks- interval. Ten mice were exposed to sand flies in two repeats of the experiment (four and six mice in particular experiments). Two mice were exposed in the same cage to approximately 200 sand fly females and values from each pair were summed. Fed sand fly females were separated and maintained at $26^{\circ} \mathrm{C}$ on $50 \%$ aqueous sucrose solution. Eight days PBM females were dissected and their guts examined under the light microscope. Intensities and locations of infections were evaluated as described previously [18].

\section{Xenodiagnosis II}

The second series of xenodiagnosis using five mice infected with $L$. donovani was done between weeks 9 and 15 p.i. $P$. orientalis females were allowed to feed on the whole body of anesthetized mice, fed females were picked out based on where they had fed and separated according to the place of feeding to four groups (a) inoculated ear, (b) contralateral ear, (c) front paws, (d) hind paws together with tail. Females were maintained on $50 \%$ aqueous sucrose solution at $26^{\circ} \mathrm{C}$ till day $2 \mathrm{PBM}$ and then stored at $-20^{\circ} \mathrm{C}$ for the subsequent analysis by qPCR. During experimental xenodiagnosis II, fed sand fly females were tested for the presence of Leishmania parasites on day 2 PBM. This shorter time interval decreased the mortality of sand fly females (from about $55 \%$ by day 8 to $8 \%$ on day 2 PBM). Sand flies fed on the inoculated ear were tested individually; sand flies fed on other parts of mice body were pooled for PCR analysis. The qPCR detection was chosen as it is an accurate method to determine the true numbers of parasites within the bloodmeal [18].

\section{Mice sampling and quantitative PCR}

Five mice (No 3, 4, 6, 8 and 10) were sacrificed eight weeks p.i., remaining five mice (No. 1, 2, 5, 7, 9) were sacrificed 15 weeks p.i. by injecting them an overdose of ketamin/xylazin anaesthesia. Both ears (inoculated and contralateral), both ear-draining lymph nodes, spleen, liver, paws, tail and in 6 mice also blood were stored at $-20^{\circ} \mathrm{C}$ for $\mathrm{qPCR}$. Extraction of total DNA from mice tissues and sand flies was performed using a DNA tissue isolation kit (Roche Diagnostics, Indianapolis, IN) according to the manufacturer's instructions. Q PCR for detection and quantification of Leishmania parasites was performed in Bio-Rad iCycler\&iQ Real-Time PCR Systems using the SYBR Green detection method (iQ SYBR Green Supermix, Bio-Rad, Hercules, CA). For adequate sensitivity, minicircle kinetoplast DNA (kDNA) was chosen as the molecular target, using the primers described by [16] (forward primer 5'-CTTTTCTGGTCCTCCGGGTAGG$3^{\prime}$ and reverse primer 5'-CCACCCGGCCCTATTTTACACCAA-3').

\section{Ethical considerations}

Animals were maintained and handled in the animal facility of Charles University in Prague in accordance with institutional guidelines and Czech legislation (Act No. 246/1992 and 359/2012 coll. on Protection of Animals against Cruelty in present statutes at large), which complies with all relevant European Union and international guidelines for experimental animals. All the experiments were approved by the Committee on the Ethics of Laboratory Experiments of the Charles University in Prague and were performed under permission no. 
MSMT-31114/2013-13 of the Ministry of the Environment of the Czech Republic. Investigators are certificated for experimentation with animals by the Ministry of Agriculture of the Czech Republic.

\section{Results}

Xenodiagnosis experiment I: week $\mathbf{2}-\mathbf{8}$ post inoculation All of the ten mice infected in their ear pinnae with $L$. donovani did not show any external signs of the disease throughout the entire experiment; no weight loss, dehydration, alopecia, hunched posture and/or scabs or sores were observed in any experimental animal. $P$. orientalis females were allowed to feed at the site of parasite inoculation on weeks $2,4,6$ and 8 post infection (p.i). In total, 430 fed females were dissected and checked for Leishmania infections eight days post blood meal (PBM) to allow the development of mature infections (Table 1). The average infectiousness of mice to feeding $P$. orientalis females steadily increased from week 2 p.i. (15\% of sand flies positive) to week 8 p.i ( $22 \%$ of sand flies positive), however, the differences were not statistically significant. Sand fly infections were characterized by dense parasite colonization of the stomodeal valve in $76 \%(65 / 86)$ of the infected $P$. orientalis females indicating these females were competent to transmit the parasites by bite [19].

In four of five mice sacrificed on week 8 p.i., qPCR demonstrated the highest parasite numbers in the inoculated ears and their draining lymph nodes with fewer parasites found in the spleens. In one of these mice, parasites were also detected in the liver. In the fifth mouse, the highest parasites burden was found in the spleen and, in contrast to other mice, parasites were also found in the blood. Other organs tested (contra-lateral ears and their draining lymph nodes, paws and tails) were negative in all five mice (Table 2).

\section{Xenodiagnosis experiment II: week 9 - 15 post} inoculation

Sand flies were allowed to feed on different body parts of five $L$. donovani-infected anaesthetized mice. Engorged females were sorted into groups having fed on (a) inoculated ears, (b) contralateral ears, (c) front paws (d) hind paws with tails. In total, 1,314 sand flies were tested by qPCR on day 2 PMB for the presence of Leishmania DNA.

The percentage of sand fly females that became infected by feeding on the inoculated ears of mice, ranged from 0 to $45 \%$. Parasite numbers extrapolated from the qPCR values, of females tested on day 2 $\mathrm{PBM}$, ranged between 10 and $4 \times 10^{4}$ with median 250 per infected sand fly (Table 3 ). From week 9 through week 12 p.i. the infectiousness to sand flies that fed on the inoculated ear did not differ significantly; the percentage of females that became infected ranged from $12.5 \%$ to $24.4 \%(\mathrm{p}=0.2)$. On the contrary, on week 15 p.i. such infection rate decreased significantly $(6.3 \% ; \mathrm{p}=0.01)$. By week 12 p.i. some sand flies feeding on the contralateral ears of two of the mice also became infected, however on week 15 p.i. no Leishmania DNA was detected in pools of females that fed on the contralateral ear. Sand flies feeding on paws or tails were not infected throughout the experiment (Table 3).

Although all through the experiment, none of the mice showed any sign of disease, following their sacrifice (week 15 p.i.), PCR showed that all five mice harbored parasites in the inoculated ears (Table 2). In three mice, parasites were also found in the corresponding draining lymph nodes (very high burdens), as well as the spleen and liver. In the two mice in which the contralateral ears became infectious to biting sand flies, parasite DNA was detected in them as well. Mice with higher parasite numbers in the ears (5, 7 and 9) were more infectious to sand flies than mice with lower parasite burdens (1 and 2).

Table 1 Infectiousness of BALB/c mice for Phlebotomus orientalis feeding on inoculated ears: first series of xenodiagnoses

\begin{tabular}{|c|c|c|c|c|c|c|c|c|c|c|c|c|}
\hline \multirow{2}{*}{$\begin{array}{l}\text { Mouse } \\
\text { No. } \\
\text { Weeks } \\
\text { p.i. }\end{array}$} & \multicolumn{2}{|c|}{$\# 1$ and $\# 2^{*}$} & \multicolumn{2}{|c|}{$\# 3$ and \#4 } & \multicolumn{2}{|c|}{$\# 5$ and \#6 } & \multicolumn{2}{|c|}{ \#7 and \#8 } & \multicolumn{2}{|c|}{$\# 9$ and $\# 10$} & \multicolumn{2}{|l|}{ Total } \\
\hline & $\begin{array}{l}\text { No fed } \\
\text { females }\end{array}$ & $\begin{array}{l}\text { No }(\%) \\
\text { positive }\end{array}$ & $\begin{array}{l}\text { No fed } \\
\text { females }\end{array}$ & $\begin{array}{l}\text { No }(\%) \\
\text { positive }\end{array}$ & $\begin{array}{l}\text { No fed } \\
\text { females }\end{array}$ & $\begin{array}{l}\text { No }(\%) \\
\text { positive }\end{array}$ & $\begin{array}{l}\text { No fed } \\
\text { females }\end{array}$ & $\begin{array}{l}\text { No }(\%) \\
\text { positive }\end{array}$ & $\begin{array}{l}\text { No fed } \\
\text { females }\end{array}$ & $\begin{array}{l}\text { No }(\%) \\
\text { positive }\end{array}$ & $\begin{array}{l}\text { No fed } \\
\text { females }\end{array}$ & $\begin{array}{l}\text { No }(\%) \\
\text { positive }\end{array}$ \\
\hline 2 & 7 & $0(0)$ & 7 & $1(14.3)$ & 11 & $2(18.2)$ & 8 & $2(25.0)$ & 0 & - & 33 & $5(15.2)$ \\
\hline 4 & 0 & - & 14 & $1(7.1)$ & 17 & $4(23.5)$ & 20 & $5(25.0)$ & 20 & $3(15.0)$ & 71 & $13(18.3)$ \\
\hline 6 & 58 & $11(19.0)$ & 69 & $12(17.4)$ & 30 & $6(20.0)$ & 37 & $8(21.6)$ & 30 & $8(26.7)$ & 224 & $45(20.1)$ \\
\hline 8 & 15 & $3(20.0)$ & 14 & $5(35.7)$ & 39 & $6(15.4)$ & 13 & $3(23.1)$ & 21 & $6(28.6)$ & 102 & $23(22.5)$ \\
\hline Total & 80 & $14(17.5)$ & 104 & 19 (18.3) & 97 & 18 (18.6) & 78 & $18(23.1)$ & 71 & $17(23.9)$ & 430 & $86(20.0)$ \\
\hline
\end{tabular}

Sand flies were dissected and checked under a light microscope 8 days post feeding on the mouse ear (site of $L$. donovani inoculation). p.i., post infection; ${ }^{*}$, two BALB/c mice were exposed to sand flies in one cage. 
Table 2 Presence of Leishmania donovani DNA in various tissues of BALB/c mice

\begin{tabular}{|c|c|c|c|c|c|c|c|c|c|c|}
\hline & \multicolumn{5}{|c|}{ Mice sacrificed 8 weeks p.i. } & \multicolumn{5}{|c|}{ Mice sacrificed 15 weeks p.i. } \\
\hline & $\# 3$ & $\# 4$ & \#6 & \#8 & $\# 10$ & $\# 1$ & $\# 2$ & \#5 & \#7 & $\# 9$ \\
\hline Inoculated ear (IE) & ++ & +++ & ++++ & ++++ & neg. & + & ++ & +++ & ++++ & ++++ \\
\hline Contralateral ear (CE) & neg. & neg. & neg. & neg. & neg. & neg. & neg. & neg. & + & ++ \\
\hline Draining lymph node of the IE & +++ & +++ & ++++ & ++++ & neg. & neg. & neg. & ++++ & +++++ & +++++ \\
\hline Draining lymph node of the CE & neg. & neg. & neg. & neg. & neg. & neg. & neg. & neg. & neg. & neg. \\
\hline Paws & neg. & neg. & neg. & neg. & neg. & neg. & neg. & neg. & neg. & neg. \\
\hline Tail & neg. & neg. & neg. & neg. & neg. & neg. & neg. & neg. & neg. & neg. \\
\hline Spleen* & + & ++ & + & ++ & +++ & neg. & neg. & ++ & ++ & ++ \\
\hline Liver & neg. & neg. & neg. & + & neg. & neg. & neg. & + & ++ & ++ \\
\hline Blood & n.d. & n.d. & neg. & neg. & ++ & n.d. & n.d & neg. & neg. & neg. \\
\hline
\end{tabular}

*Spleens of mice 5, 7 and 9 were positive also by parasite cultivation; in other mice cultivation attempts were not done. Quantity of parasites was tested by qPCR and scored as $+\left(<10^{2}\right),++\left(10^{2}-10^{3}\right),+++\left(10^{3}-10^{4}\right),++++\left(10^{4}-10^{5}\right),+++++\left(>10^{5}\right)$. neg., negative, n.d., not done; p.i., post infection.

\section{Discussion}

We used BALB/c mice to perform xenodiagnosis of $L$. donovani infections in order to establish tools for studying the putative role of asymptomatic parasite carriers in the transmission dynamics of VL. BALB/c mice are classified as susceptible to $L$. donovani with the capacity to heal visceralizing Leishmania infections spontaneously (reviewed by [20]). Thus, in our study BALB/c mice represented asymptomatic humans that comprise the majority of L. donovani infections encountered in endemic areas [20] and not the relatively rare, patent VL cases. $\mathrm{BALB} / \mathrm{c}$ mice infected with $L$. donovani developed persistent burden of parasites at the site of inoculation, draining lymph nodes and internal organs with only limited dissemination to the contralateral ears. Ear tissues and their draining lymph nodes exhibited heavy parasite burdens, with parasites in lymph nodes often outnumbering those found in ears. Since parasites were not normally detected in blood, we assume that the relevant parasite burdens are those in the skin and are almost exclusively localized close to the site of the infective bite. It is not known whether skin burdens of $L$. donovani in asymptomatic humans are also restricted to the region of the infectious bite. One indication that this may be the case derives from PKDL patients in whom parasiteladen nodules are normally more common in the limbs, neck and face - body parts exposed to biting sand flies [21]. Studies on L. infantum, the causative parasite of VL in Latin America, demonstrated high parasite densities in the skin (higher than lymph nodes or viscera) in both symptomatic and asymptomatic dogs [22]. Furthermore, a strong correlation between the parasite load in ear tissue and the infectiousness to Lutzomyia longipalpis, the main vector species, was demonstrated in symptomatic dogs in Brazil [23,24].

Tissue tropisms and host virulence of Leishmania parasites is influenced by many factors. An important role is played by Leishmania species-specific genes [25], but the mode of infection (intradermal $v s$. intravenous), the size of the parasite inoculum as well as the Leishmania life-cycle stages (procyclic vs. metacyclic) used, all influence the outcome of infection. VL initiated by sand fly bite has not been studied in mice but has recently been described in hamsters where VL progressed slowly resembling the chronicity of the disease in humans [26]. However, most of the experiments with $\mathrm{BALB} / \mathrm{c}$ mice employed the intravenous route of infection, resulting in rapid visceralization, unlike the progression of VL in humans (reviewed by [27]). The intradermal route of infection, used in the current study, is closer to the natural mode of transmission since parasites are exposed to the localized immune responses in the skin [28]. In addition, isolation of parasites from the thoracic midguts of infected sand flies facilitated the inoculation of a known number of predominantly metacyclic stage parasites. This standardized procedure resulted in infections without external signs of disease that visceralized, while the dermal inoculation sites remained infectious to biting sand flies. The percentage of $P$. orientalis infected with L. donovani while biting at or close to the site of inoculation (approximately 19\%) was similar to that observed for other natural vectors; $L$. longipalpis feeding on symptomatic dogs infected with $L$. d. infantum in Brazil (1328\%, [23,29-32]).

Previous studies have demonstrated that progression of Leishmania infections in susceptible hosts is influenced by the infective dose [33]. The number of parasites transmitted by sand flies to the host has been shown to be greatly variable [33-35]. The infective dose per mouse used in our experiment $\left(9 \times 10^{4}-10^{5}\right)$, was significantly lower than inoculums normally delivered by needle-injection $\left(10^{6}-10^{9}\right.$ parasites, reviewed by [36]) and equaled or only slightly exceeded the upper range detected in experiments with $P$. duboscqi transmitting $L$. 
Table 3 Infectiousness of BALB/c mice for Phlebotomus orientalis: second series of xenodiagnoses

\begin{tabular}{|c|c|c|c|c|c|c|c|c|c|c|c|}
\hline \multirow{3}{*}{$\begin{array}{l}\text { Mouse } \\
\text { No. }\end{array}$} & \multirow{3}{*}{$\begin{array}{l}\text { Site of } \\
\text { feeding of } \\
\text { sand flies }\end{array}$} & \multicolumn{10}{|c|}{ Weeks post-infection } \\
\hline & & \multicolumn{2}{|l|}{9} & \multicolumn{2}{|l|}{10} & \multicolumn{2}{|l|}{11} & \multicolumn{2}{|l|}{12} & \multicolumn{2}{|l|}{15} \\
\hline & & $\begin{array}{l}\text { No fed } \\
\text { females }\end{array}$ & $\begin{array}{l}\text { No }(\%) \\
\text { positive }\end{array}$ & $\begin{array}{l}\text { No fed } \\
\text { females }\end{array}$ & $\begin{array}{l}\text { No }(\%) \\
\text { positive }\end{array}$ & $\begin{array}{l}\text { No fed } \\
\text { females }\end{array}$ & $\begin{array}{l}\text { No }(\%) \\
\text { positive }\end{array}$ & $\begin{array}{l}\text { No fed } \\
\text { females }\end{array}$ & $\begin{array}{l}\text { No }(\%) \\
\text { positive }\end{array}$ & $\begin{array}{l}\text { No fed } \\
\text { females }\end{array}$ & $\begin{array}{l}\text { No }(\%) \\
\text { positive }\end{array}$ \\
\hline \multirow[t]{4}{*}{$\# 1$} & Inoculated ear & 13 & $1(7.7)^{a}$ & 9 & 0 & 21 & $3(14.3)^{b}$ & 15 & $1(6.7)^{c}$ & 6 & 0 \\
\hline & $\begin{array}{l}\text { Contralateral } \\
\text { ear }\end{array}$ & 3 & 0 & 13 & 0 & 6 & 0 & 18 & 0 & 5 & 0 \\
\hline & Front paws & 8 & 0 & 7 & 0 & 4 & 0 & 9 & 0 & 9 & 0 \\
\hline & $\begin{array}{l}\text { Hind paws } \\
\text { and tail }\end{array}$ & 28 & 0 & 7 & 0 & 12 & 0 & 9 & 0 & 10 & 0 \\
\hline \multirow[t]{4}{*}{ \#2 } & Inoculated ear & 20 & $4(20.0)^{d}$ & 6 & 0 & 12 & $1(8.3)^{\mathrm{e}}$ & 14 & 0 & 8 & 0 \\
\hline & $\begin{array}{l}\text { Contralateral } \\
\text { ear }\end{array}$ & 4 & 0 & 16 & 0 & 10 & 0 & 13 & 0 & 5 & 0 \\
\hline & Front paws & 7 & 0 & 6 & 0 & 9 & 0 & 14 & 0 & 15 & 0 \\
\hline & $\begin{array}{l}\text { Hind paws } \\
\text { and tail }\end{array}$ & 4 & 0 & 5 & 0 & 3 & 0 & 9 & 0 & 10 & 0 \\
\hline \multirow[t]{4}{*}{ \#5 } & Inoculated ear & 23 & $5(25.0)^{f}$ & 28 & $3(10.7)^{\mathrm{g}}$ & 27 & $10(37.0)^{h}$ & 19 & $5(26.3)^{i}$ & 41 & $3(7.3)^{j}$ \\
\hline & $\begin{array}{l}\text { Contralateral } \\
\text { ear }\end{array}$ & 11 & 0 & 24 & 0 & 40 & 0 & 12 & 0 & 10 & 0 \\
\hline & Front paws & 3 & 0 & 17 & 0 & 17 & 0 & 13 & 0 & 11 & 0 \\
\hline & $\begin{array}{l}\text { Hind paws } \\
\text { and tail }\end{array}$ & 19 & 0 & 15 & 0 & 29 & 0 & 5 & 0 & 10 & 0 \\
\hline \multirow[t]{4}{*}{ \#7 } & Inoculated ear & 20 & $2(13.3)^{k}$ & 18 & $2(11.1)^{1}$ & 16 & $0(0)$ & 18 & $6(33.3)^{m}$ & 11 & $1(9.0)^{n}$ \\
\hline & $\begin{array}{l}\text { Contralateral } \\
\text { ear }\end{array}$ & 14 & 0 & 22 & 0 & 20 & 0 & 8 & pos. & 14 & 0 \\
\hline & Front paws & 3 & 0 & 7 & 0 & 9 & 0 & 6 & 0 & 5 & 0 \\
\hline & $\begin{array}{l}\text { Hind paws } \\
\text { and tail }\end{array}$ & 0 & 0 & 26 & 0 & 6 & 0 & 8 & 0 & 10 & 0 \\
\hline \multirow[t]{4}{*}{$\# 9$} & Inoculated ear & 15 & $8(34.7)^{\circ}$ & 35 & $7(20.0)^{\mathrm{p}}$ & 18 & $4(22.2)^{q}$ & 20 & $9(45.0)^{r}$ & 13 & $1(7.7)^{5}$ \\
\hline & $\begin{array}{l}\text { Contralateral } \\
\text { ear }\end{array}$ & 20 & 0 & 12 & 0 & 17 & 0 & 27 & pos. & 8 & 0 \\
\hline & Front paws & 9 & 0 & 6 & 0 & 3 & 0 & 9 & 0 & 8 & 0 \\
\hline & $\begin{array}{l}\text { Hind paws } \\
\text { and tail }\end{array}$ & 8 & 0 & 23 & 0 & 9 & 0 & 32 & 0 & 5 & 0 \\
\hline \multirow[t]{4}{*}{$\Sigma$} & Inoculated ear & 91 & $20(22.0)$ & 96 & $12(12.5)$ & 94 & $18(19.1)$ & 86 & $21(24.4)$ & 79 & $5(6.3)$ \\
\hline & $\begin{array}{l}\text { Contralateral } \\
\text { ear }\end{array}$ & 52 & 0 & 87 & 0 & 93 & 0 & 78 & 2/5 pools & 42 & 0 \\
\hline & Front paws & 30 & 0 & 43 & 0 & 42 & 0 & 51 & 0 & 48 & 0 \\
\hline & $\begin{array}{l}\text { Hind paws } \\
\text { and tail }\end{array}$ & 59 & 0 & 76 & 0 & 59 & 0 & 63 & 0 & 45 & 0 \\
\hline
\end{tabular}

Engorged sand flies were maintained on $50 \%$ aqueous sucrose solution till day 2 post-blood meal at $26^{\circ} \mathrm{C}$ and then tested by qPCR for presence and quantity of Leishmania donovani DNA. Sand flies fed on the inoculated ear were tested individually; sand flies fed on other parts of mice body were pooled for PCR analysis. p.i., post infection, pos. = positive pool, a-s, numbers of Leishmania detected by qPCR: a, 320; b, all <10; c, <10; d, 1652, 419, 643, 297; e, 430; o, 708, 21, 245, 27, $476,4035,24,68 ; \mathrm{p}, 1850,211,39,3216,74,48,162 ; \mathrm{q}, 18,143,2161,614 ; \mathrm{r}, 20,481,5031,50,21,171,572,228,17 ; \mathrm{s}, 279 ; \mathrm{f}, 153,113,168,404,665 ; \mathrm{g}, 69,1286$, $517 ; \mathrm{h}, 1574,37,30,11085,1021,15,2844,137,64,1815 ; \mathrm{i}, 425,100,444,1917,2186 ; \mathrm{j}, 273,860,50 ; \mathrm{k} ; 143,180 ; \mathrm{l}, 60,1333 ; \mathrm{m}, 146,382,40049,66,151,1123 ; \mathrm{n}, 256$.

major $\left(10^{5}\right.$ parasites inoculated per bite [33]) and P. perniciosus and $L$. longipalpis transmitting $L$. infantum $\left(4 \times 10^{4}\right.$ and $10^{4}$ parasites per bite, respectively) [34,35]. Importantly, this infective dose comprised $65-73 \%$ metacyclics which closely approximate the mean percentage of $L$. donovani and $L$. infantum metacyclics transmitted by L. longipalpis (66-82\%) [26].
Transmission of $L$. donovani is assumed to be chiefly anthroponotic unlike $L$. infantum that circulates as a classical zoonosis with dogs serving as the main reservoir hosts [37]. However, recent findings suggest that reservoir animals may contribute to the transmission of $L$. donovani as well. For example, high levels of seroprevalence and confirmed infections with $L$. donovani 
were found in dogs in Sudan [38] while qPCR results indicated the possibility that goats were infected with $L$. donovani in Nepal and India [39]. Finding PCR positive animals does not necessarily mean they serve as parasite reservoirs for biting sand flies. Indeed, such animals may simply serve as parasite sinks, i.e. animals upon which infected sand flies feed but do not contribute to their infection. Therefore, animal models for studying $L$. donovani development in the host and its subsequent infectiousness to sand flies, warrant in-depth studies in the laboratory and in the field.

$\mathrm{BALB} / \mathrm{c}$ mice are well established animal models for studying host-parasite interactions, pathogenesis, immunological responses and vaccines against VL $[20,36]$. Our study established that BALB/c mice infected with $L$. donovani did not develop external signs of disease and are highly infectious to biting sand flies, making them a suitable laboratory animal for xenodiagnostic studies as well. The fact that apparently healthy ear tissue maintains sufficient quantities of $L$. donovani amastigotes to induce heavy infections in sand fly vectors, points to the need for further studies evaluating wild rodents in endemic foci as potential reservoir hosts for $L$. donovani.

\section{Conclusions}

This is the first paper to characterize the infectiousness profile for biting sand flies of hosts without external signs of disease infected with $L$. donovani. We established here an animal model using BALB/C mice inoculated intradermally with infective-stage (metacyclic) parasites isolated from experimentally infected sand flies. This approach enabled the counting of exact numbers of parasites in the inoculums while the site of inoculation and parasite forms used, remained similar to those delivered during infected sand fly bites. Experimentally infected mice harbored $L$. donovani parasites for many weeks without showing any apparent symptoms. They developed persistent parasitaemias at the site of inoculation, draining lymph nodes and internal organs with only limited dissemination to the contralateral ears. Although, like asymptomatic human cases, infected mice did not show signs of disease, they were highly infectious to $P$. orientalis, the vector of VL in north Ethiopia and Sudan. The study showed that BALB/c mice comprise a suitable laboratory model for performing xenodiagnosis of $L$. donovani infections and warrants the consideration of rodents as potential reservoir hosts of $L$. donovani. Data about temporal and spatial patterns of infectiousness of $L$. donovani infected mice for sand flies showed that parasites persist in the inoculation site and are found transmissible for months to sand flies biting on the same site. This finding may promote improved understanding of the transmission dynamics and epidemiology of VL.

\section{Abbreviations}

VL: Visceral leishmaniasis; CL: Cutaneous leishmaniasis; LST: Leishmanin skin test; PKDL: Post-kala-azar dermal leishmaniasis; PBM: Post bloodmeal; p.i.: Post infection; neg.: Negative; n.d: Not done.

\section{Competing interests}

The authors declare that they have no competing interests.

\section{Authors' contributions}

Substantial contribution to conception and design: JS, PV, acquisition of data: JS, VS, JV, interpretation of data: JS, JV, VS, PV, drafting the article: JS, AW, PV, revising the article for important intellectual content: AW, PV, JS. All authors read and approved the final version of the manuscript.

\section{Acknowledgements}

We would like to thank to Prof. Teshome Gebre-Michael and Prof. Asrat Hailu, Addis Ababa University, Ethiopia, for kindly providing the progeny of the $P$. orientalis colony and the L. donovani isolate. This work was supported by Czech Science Foundation [13-07500S], the Bill and Melinda Gates Foundation Global Health Program [OPPGH5336 to A.W.], EDENext [2011-261504 to P.V.] where the paper is cataloged by the EDENext Steering Committee as EDENext280, by EurNegVec COST Action [TD1303] and COST-CZ LD [14076].

\section{Author details}

'Department of Parasitology, Faculty of Science, Charles University in Prague, Prague 2 Vinicna 7, 128 44, Czech Republic. ${ }^{2}$ Department of Microbiology \& Molecular Genetics, The Institute for Medical Research Israel-Canada, The Kuvin Centre for the Study of Infectious \& Tropical Diseases, The Hebrew University - Hadassah Medical School, The Hebrew University of Jerusalem, Jerusalem 91120, Israel.

Received: 12 December 2014 Accepted: 24 February 2015

Published online: 14 March 2015

\section{References}

1. Alvar J, Velez ID, Bern C, Herrero M, Desjeux P, Cano J, et al. Leishmaniasis worldwide and global estimates of its incidence. PLoS One. 2012;7:e35671.

2. Bern C, Maguire JH, Alvar J. Complexities of assessing the disease burden attributable to leishmaniasis. PLoS Negl Trop Dis. 2008;2:e313.

3. Singh OP, Hasker E, Sacks D, Boelaert M, Sundar S. Asymptomatic Leishmania infection: a new challenge for Leishmania control. Clin Infect Dis. 2014;58:1424-9.

4. Stauch A, Sarkar RR, Picado A, Ostyn B, Sundar S, Rijal S, et al. Visceral leishmaniasis in the Indian subcontinent: modelling epidemiology and control. PLoS Negl Trop Dis. 2011;5:e1405.

5. Miller E, Warburg A, Novikov I, Hailu A, Volf P, Seblova V, et al. Quantifying the contribution of hosts with different parasite concentrations to the transmission of visceral leishmaniasis in Ethiopia. PLoS Negl Trop Dis. 2014;8:e3288.

6. Seblova V, Volfova V, Dvorak V, Pruzinova K, Votypka J, Kassahun A, et al. Phlebotomus orientalis sand flies from two geographically distant Ethiopian localities: biology, genetic analyses and susceptibility to Leishmania donovani. PLoS Negl Trop Dis. 2013;7:e2187.

7. Quinnell RJ, Courtenay O. Transmission, reservoir hosts and control of zoonotic visceral leishmaniasis. Parasitology. 2009;136:1915-34.

8. Costa CHN, Gomes RBB, Silva MRB, Garcez LM, Ramos PKS, Santos RS, et al Competence of the human host as a reservoir for Leishmania chagasi. J Infect Dis. 2000;182:997-1000.

9. Gidwani K, Rai M, Chakravarty J, Boelaert M, Sundar S. Evaluation of leishmanin skin test in Indian visceral leishmaniasis. Am J Trop Med Hyg 2009:80:566-7.

10. Molina R, Lohse JM, Pulido F, Laguna R, Lopez-Velez R, Alvar J. Infection of sand flies by humans coinfected with Leishmania infantum and human immunodeficiency virus. Am J Trop Med Hyg. 1999;60:51-3.

11. Kamhawi $\mathrm{S}$. The biological and immunomodulatory properties of sand fly saliva and its role in the establishment of Leishmania infections. Microbes Infect. 2000;2:1765-73.

12. Ribeiro JMC. Blood-feeding arthropods: live syringes or invertebrate pharmacologists? Infect Agent Dis. 1995;4:143-52.

13. Sacks D, Kamhawi S. Molecular aspects of parasite-vector and vector-host interactions in Leishmaniasis. Ann Rev Microbiol. 2001;55:453-83. 
14. Ready PD. Biology of phlebotomine sand flies as vectors of disease agents. Annu Rev Entomol. 2013:58:227-50.

15. Volf $P$, Volfova $V$. Establishment and maintenance of sand fly colonies. J Vector Ecol. 2011;36 Suppl 1:S1-9.

16. Sadlova J, Dvorak V, Seblova V, Warburg A, Votypka J, Volf P. Sergentomyia schwetzi is not a competent vector for Leishmania donovani and other Leishmania species pathogenic to humans. Parasit Vectors. 2013;6:186.

17. Sadlova J, Price HP, Smith BA, Votypka J, Volf P, Smith DF. The stageregulated HASPB and SHERP proteins are essential for differentiation of the protozoan parasite Leishmania major in its sand fly vector, Phlebotomus papatasi. Cell Microbiol. 2010;12:1765-79.

18. Myskova J, Votypka J, Volf P. Leishmania in sand flies: comparison of quantitative polymerase chain reaction with other techniques to determine the intensity of infection. J Med Entomol. 2008;45:133-8.

19. Volf P, Hajmova M, Sadlova J, Votypka J. Blocked stomodeal valve of the insect vector: similar mechanism of transmission in two trypanosomatid models. Int J Parasitol. 2004;34:1221-7.

20. Wilson ME, Jeronimo SM, Pearson RD. Immunopathogenesis of infection with the visceralizing Leishmania species. Microb Pathog. 2005;38:147-60.

21. Garg VK, Agrawal S, Rani S, Joshi A, Agarwalla A, Das ML, et al. Post-kala-azar dermal leishmaniasis in Nepal. Int J Dermatol. 2001:40:179-84.

22. Lima LVR, Carneiro LA, Campos MB, Chagas EJ, Laurenti MD, Corbett CEP, et al. Canine visceral Leishmaniasis Due to Leishmania (L.) Infantum chagasi in Amazonian brazil: comparison of the parasite density from the skin, lymph node and visceral tissues between symptomatic and asymptomatic seropositive dogs. Rev Inst Med Trop Sao Paulo. 2010;52:259-65.

23. Michalsky EM, Rocha MF, da Rocha Lima AC, Franca-Silva JC, Pires MQ, Oliveira FS, et al. Infectivity of seropositive dogs, showing different clinical forms of leishmaniasis, to Lutzomyia longipalpis phlebotomine sand flies. Vet Parasitol. 2007:147:67-76.

24. Amorim IF, Silva SM, Figueiredo MM, Moura EP, Castro RS, Lima TK, et al. Toll receptors type-2 and CR3 expression of canine monocytes and its correlation with immunohistochemistry and xenodiagnosis in visceral leishmaniasis. PLoS One. 2011;6:e27679.

25. Zhang WW, Matlashewski G. Screening Leishmania donovani-specific genes required for visceral infection. Mol Microbiol. 2010;77:505-17.

26. Aslan H, Dey R, Meneses C, Castrovinci P, Jeronimo SM, Oliva G, et al. A new model of progressive visceral leishmaniasis in hamsters by natural transmission via bites of vector sand flies. J Infect Dis. 2013;207:1328-38.

27. McCall LI, Zhang WW, Matlashewski G. Determinants for the development of visceral leishmaniasis disease. PLoS Pathog. 2013;9:e1003053.

28. Ahmed S, Colmenares M, Soong L, Goldsmith-Pestana K, Munstermann L, Molina $R$, et al. Intradermal infection model for pathogenesis and vaccine studies of murine visceral leishmaniasis. Infec Immun. 2003;71:401-10.

29. Courtenay O, Quinnell RJ, Garcez LM, Shaw JJ, Dye C. Infectiousness in a cohort of brazilian dogs: why culling fails to control visceral leishmaniasis in areas of high transmission. J Infect Dis. 2002;186:1314-20.

30. Soares MR, de Mendonca IL, do Bonfim JM, Rodrigues JA, Werneck GL, Costa CH. Canine visceral leishmaniasis in Teresina, Brazil: Relationship between clinical features and infectivity for sand flies. Acta Trop. 2011;117:6-9.

31. Laurenti MD, Rossi CN, Matta VL, Tomokane TY, Corbett CE, Secundino NF, et al. Asymptomatic dogs are highly competent to transmit Leishmania (Leishmania) infantum chagasi to the natural vector. Vet Parasitol. 2013;196:296-300.

32. Travi BL, Tabares CJ, Cadena H, Ferro C, Osorio Y. Canine visceral leishmaniasis in Colombia: relationship between clinical and parasitologic status and infectivity for sand flies. Am J Trop Med Hyg. 2001;64:119-24.

33. Kimblin N, Peters N, Debrabant A, Secundino N, Egen J, Lawyer P, et al. Quantification of the infectious dose of Leishmania major transmitted to the skin by single sand flies. Proc Natl Acad Sci U S A. 2008;105:10125-30.

34. Maia C, Seblova V, Sadlova J, Votypka J, Volf P. Experimental transmission of Leishmania infantum by two major vectors: a comparison between a viscerotropic and a dermotropic strain. PLoS Negl Trop Dis. 2011;5:e1181.

35. Secundino NFC, de Freitas VC, Monteiro CC, Pires ACAM, David BA, Pimenta PFP. The transmission of Leishmania infantum chagasi by the bite of the Lutzomyia longipalpis to two different vertebrates. Parasit Vectors. 2012;5:20.

36. Garg R, Dube A. Animal models for vaccine studies for visceral leishmaniasis. Indian J Med Res. 2006;123:439-54.
37. Bern C, Courtenay O, Alvar J. Of cattle, sand flies and men: a systematic review of risk factor analyses for South Asian visceral leishmaniasis and implications for elimination. PLoS Negl Trop Dis. 2010;4:e599.

38. Dereure J, El-Safi SH, Bucheton B, Boni M, Kheir MM, Davoust B, et al. Visceral leishmaniasis in eastern Sudan: parasite identification in humans and dogs: host-parasite relationships. Microbes Infect. 2003;5:1103-8.

39. Singh N, Mishra J, Singh R, Singh S. Animal reservoirs of visceral leishmaniasis in India. J Parasitol. 2013;99:64-7.

\section{Submit your next manuscript to BioMed Central and take full advantage of:}

- Convenient online submission

- Thorough peer review

- No space constraints or color figure charges

- Immediate publication on acceptance

- Inclusion in PubMed, CAS, Scopus and Google Scholar

- Research which is freely available for redistribution

Submit your manuscript at www.biomedcentral.com/submit
C Biomed Central 